Journal of Telenursing (JOTING)

Volume 1, Nomor 1, Juni 2019

e-ISSN : 2684-8988

p-ISSN : 2684-8996

DOI: https://doi.org/10.31539/joting.v1i1.496

\title{
PENGARUH STORYTELLING DAN GUIDED-IMAGERY TERHADAP TINGKAT PERUBAHAN KECEMASAN ANAK USIA PRASEKOLAH YANG DILAKUKAN TINDAKAN INVASIF
}

\author{
Julita Rosalia Legi ${ }^{1}$, Suhendar Sulaiman ${ }^{2}$, Nyimas Heny Purwanti ${ }^{3}$ \\ Universitas Pembangunan Indonesia Manado ${ }^{1}$ \\ Universitas Muhammadiyah Jakarta ${ }^{2,3}$ \\ julitalegi@gmail.com ${ }^{1}$
}

\begin{abstract}
ABSTRAK
Penelitian ini bertujuan untuk mengidentifikasi pengaruh storytelling dan guided imagery terhadap perubahan tingkat kecemasan anak usia prasekolah yang akan dilakukan tindakan invasif (pemasangan infus). Desain penelitian yang digunakan adalah quasi eksperiment. Hasil penelitian menunjukkan rata-rata tingkat kecemasan anak yang mendapatkan intervensi storytelling sebesar 2.11 untuk kelompok anak yang ditemani orangtua dan 2.50 untuk kelompok anak yang tidak ditemani orangtua. Sedangkan, rata-rata tingkat kecemasan anak dengan intervensi guided imagery sebesar 2.17 pada kelompok anak yang ditemani orangtua dan 2.33 pada kelompok anak yang tidak ditemani orangtua. Hasil uji statistik menunjukkan ada pengaruh storytelling dan guided imagery terhadap penurunan tingkat kecemasan anak usia prasekolah yang dilakukan tindakan invasif (pemasangan infus). Simpulan, storytelling kepada kelompok anak usia prasekolah yang ditemani orangtua lebih berpengaruh dibandingkan kepada anak yang tidak ditemani orangtua.
\end{abstract}

Kata Kunci: Guided-imagery, Kecemasan Anak Prasekolah, Storytelling

\begin{abstract}
This study aims to identify the effect of storytelling and guided imagery on changes in anxiety levels of preschool children who will be subjected to invasive action (infusion). The research design used was a quasi experiment. The results showed that the average level of anxiety of children who received storytelling intervention was 2.11 for the group of children who were accompanied by their parents and 2.50 for the group of children who were not accompanied by their parents. Meanwhile, the average level of anxiety of children with guided imagery intervention was 2.17 in the group of children accompanied by their parents and 2.33 in the group of children who were not accompanied by their parents. The results of statistical tests show that there is an effect of storytelling and guided imagery on reducing anxiety levels of preschool children who are subjected to invasive action (infusion). In conclusion, storytelling to preschool age groups accompanied by parents is more influential than to children who are not accompanied by their parents.
\end{abstract}

Keywords: Guided-imagery, Preschool Anxiety, Storytelling 


\section{PENDAHULUAN}

Anak adalah individu yang selalu mengalami perubahan yaitu dimulai dari bayi hingga remaja. Pada masa pertumbuhan dan perkembangannya, anak tidak selalu dalam kondisi kesehatan yang optimal tetapi juga anak berada pada rentang sehat sakit (Mariyam, 2011). Hospitalisasi merupakan kondisi krisis bagi anak. Di rumah sakit, anak diharuskan untuk menghadapi lingkungan yang baru, pemberi asuhan keperawatan yang tidak dikenal anak dan prosedur-prosedur sehingga anak merasakan nyeri, kehilangan kemandirian anak dan hal lainnya (Wong, 2009).

Anak yang mengalami keadaan sakit disertai dengan pembatasan aktifitas harian, ketidakmampuan fisik dan pengobatan membutuhkan perawatan di rumah sakit (Mariyam, 2011). Hospitalisasi merupakan kondisi krisis bagi anak. Kondisi krisis ini terjadi karena anak mencoba beradaptasi dengan lingkungan yang dianggapnya asing dan baru, sehingga kondisi tersebut mengharuskan anak untuk berpisah dengan lingkungan yang dirasakannya aman (Oktiawati, 2017).

Di rumah sakit, anak diharuskan untuk menghadapi lingkungan yang baru, pemberi asuhan keperawatan yang tidak dikenal anak dan prosedur-prosedur sehingga anak merasakan nyeri, kehilangan kemandirian anak dan hal lainnya (Wong, 2009). Perawatan yang dijalani anak selama di rumah sakit diekspresikan sebagai suatu hukuman sehingga anak usia prasekolah merasa takut, malu dan bersalah. Ketakutan terhadap tindakan yang menimbulkan perlukaan muncul karena anak mengganggap tindakan dari prosedur yang dilakukan akan mengancam integritas tubuhnya (Oktiawati, 2017).

Pemasangan infus adalah prosedur penusukan vena dengan menggunakan over the needle catheter (ONC) untuk memasukkan obat atau cairan ke dalam pembuluh darah. Adanya penusukan vena pada pemasangan infus dapat menimbulkan rasa cemas, takut dan nyeri (Mariyam, 2011). Kecemasan yang terjadi pada anak akan menghambat prosedur yang akan dilakukan selama di rumah sakit, sehingga perlu adanya atraumatik care untuk mencegah atau meminimalisir nyeri dan cidera pada tubuh akibat prosedur yang dilakukan sehinga tidak terjadi distres psikologi pada anak (Wong, 2009).

Kecemasan yang terjadi pada anak akan menghambat prosedur yang akan dilakukan selama di rumah sakit, sehingga perlu adanya atraumatik care untuk mencegah atau meminimalisir nyeri dan cidera pada tubuh akibat prosedur yang dilakukan sehinga tidak terjadi distres psikologi pada anak (Wong, 2009). Pendekatan psikologis yang dapat dilakukan untuk mendukung intervensi asuhan keperawatan dalam membantu anak mencegah dan mengatasi kecemasan selama proses perawatan yaitu terapi seni, terapi kreatifitas, terapi bermain, terapi musik, terapi relaksasi progesif, storytelling dan guided imagery.

Storytelling adalah salah satu cara distraksi untuk mengurangi kecemasan. Storytelling yaitu kegiatan bercerita melalui kata-kata, suara dan gambar. Cerita menggambarkan model yang mengajarkan nilai dan kemampuan (Kanchan, 2015). Storytelling bertujuan untuk membantu anak mengekspresikan emosinya terhadap perubahan hidup dalam lingkungan yang nyaman, juga untuk membuka kekuatan dalam dirinya sehingga dapat meningkatkan resiliensi dalam hidupnya (Siregar, 2015).

Irmawaty (2013) dalam penelitiannya mengatakan bahwa terbukti terdapat perbedaan yang signifikan tingkat kecemasan anak usia prasekolah akibat hospitalisasi sebelum dan sesudah diberikan tindakan storytelling karena storytelling memberi sugesti kepada anak untuk rileks dan terlarut dalam cerita sehingga dapat menurunkan tingkat kecemasan. Penelitian lain yang dilakukan Siregar (2015) dalam penelitiannya 
menggunakan storytelling untuk menurunkan derajat stress pada anak dengan leukemia, perubahan derajat stres dimulai dengan terjadinya perubahan emosi negatif menjadi emosi positif.

Untuk mengurangi kecemasan pada anak, ada cara lain yang dapat digunakan yaitu dengan guided imagery. Guided imagery didefinisikan sebagai penggunaan imajinasi yang membawa pikiran atau respon tubuh yang positif. Itu merupakan proses kognitif yang menggunakan indra penglihatan, suara, bau, rasa, sentuhan dan juga perasaan bergerak yang semuanya bersama menghasilkan perubahan regeneratif di pikiran dan tubuh (Alves \& Khatarine, 2009). Penelitian yang dilakukan oleh Patasik et al., (2013) mengatakan bahwa guided imagery terbukti untuk menurunkan kecemasan karena guided imagery berpengaruh dalam sistem kontrol fisiologi tubuh, memberikan relaksasi dan menghasilkan hormon endorphin untuk membuat tenang.

Berdasarkan data dari rekam medik RSU GMIM Pancaran Kasih Manado, jumlah anak yang dirawat di ruang anak selama setahun terakhir yaitu pada bulan April 2017 April 2018 berjumlah 1105 anak, 30\% diantaranya merupakan anak usia prasekolah dan $50 \%$ anak usia prasekolah yang dirawat dipasang infus. Studi pendahuluan dilakukan di ruang rawat anak melalui wawancara dan observasi pada 6 orang anak yang di pasang infus. Melalui wawancara pada 4 orangtua anak didapatkan hasil, sebelum dilakukan tindakan pemasangan infus perawat memberikan penjelasan tentang alasan dilakukan tindakan tersebut tetapi tidak mengajarkan anak maupun orangtua teknik distraksi untuk mengurangi kecemasan, sedangkan 2 anak lainnya perawat memberitahu orang tua untuk mengajak anak berbicara sebagai tindakan mengurangi kecemasan anak. Melalui hasil observasi, 6 anak yang dilakukan pemasangan infus menunjukkan reaksi cemas, takut, marah, menangis, memberontak dan menolak untuk dilakukan pemasangan infus. Kurangnya tindakan perawat untuk mengurangi kecemasan dan ketakutan pada anak ketika akan dilakukan pemasangan infus akan membuat anak mengalami trauma psikologis.

\section{METODE PENELITIAN}

Penelitian ini merupakan penelitian kuantitatif dengan menggunakan quasi experimental, dengan rancangan penelitian non equivalent without control group (non randomized without control group pretest-posttest. Sampel dalam penelitian adalah anak usia prasekolah yang akan dilakukan tindakan invasif (pemasangan infus) di ruang rawat anak berjumlah 24 orang. Teknik yang digunakan yaitu purposive sampling. Responden dibagi dalam empat kelompok yaitu intervensi storytelling pada kelompok anak yang ditemani orangtua dan yang tidak ditemani orangtua, dan intervensi guided imagery pada kelompok anak yang ditemani orangtua dan yang tidak ditemani orangtua.

Adapun kriteria inklusi dalam penelitian ini adalah anak yang akan dilakukan tindakan pemasangan infus kedua kali, orang tua bersedia anak menjadi responden, orang tua mampu membaca, menulis dan berkomunikasi. Alat pengumpulan data menggunakan lembar observasi FAS (Face Anxiety Scale) untuk mengukur tingkat kecemasan anak.

Data diambil melalui kuesioner dari keluarga responden kemuadian Pada kelompok intervensi I merupakan anak yang ditemani keluarga dengan intervensi storytelling, akan diukur nilai kecemasannya 5 menit sebelum dilakukan pemasangan infus kemudian peneliti melakukan storytelling 1 kali. Setelah storytelling dilakukan, peneliti/ asisten peneliti mengukur nilai kecemasan anak. Pada kelompok intervensi II merupakan anak yang tidak ditemani keluarga dengan intervensi storytelling 1 kali, 
akan diukur nilai kecemasannya 5 menit sebelum dilakukan pemasangan infus kemudian peneliti melakukan storytelling. Setelah storytelling dilakukan, peneliti/ asisten peneliti mengukur nilai kecemasan anak.

Kelompok intervensi III merupakan anak yang ditemani keluarga dengan intervensi guided imagery, akan diukur nilai kecemasannya 5 menit sebelum dilakukan pemasangan infus kemudian peneliti melakukan guided imagery 1 kali. Setelah guided imagery dilakukan, peneliti/ asisten peneliti mengukur nilai kecemasan anak. Pada kelompok intervensi IV merupakan anak yang tidak ditemani keluarga dengan intervensi guided imagery $1 \mathrm{kali}$, akan diukur nilai kecemasannya 5 menit sebelum dilakukan pemasangan infus kemudian peneliti melakukan guided imagery. Setelah guided imagery dilakukan, peneliti/ asisten peneliti mengukur nilai kecemasan anak. Uji statistik yang digunakan adalah uji paired t-test karena data berdistribusi normal.

\section{HASIL PENELITIAN \\ Analisa Univariat \\ Karakteristik responden}

Tabel. 1

Distribusi Frekuensi Responden Berdasarkan Usia dan Jenis Kelamin, Tingkat Kecemasan Sebelum dan Sesudah Intervensi Storytelling dan Guided Imagery $(\mathrm{n}=24)$

\begin{tabular}{|c|c|c|c|c|c|c|c|c|}
\hline \multirow[t]{2}{*}{ Variabel } & \multicolumn{4}{|c|}{$\begin{array}{c}\text { Jumlah Kelompok } \\
\text { Responden }\end{array}$} & \multicolumn{4}{|c|}{ Presentasi (\%) } \\
\hline & $\mathrm{I}$ & II & III & IV & $\mathrm{I}$ & II & III & IV \\
\hline \multicolumn{9}{|l|}{ Usia } \\
\hline 3 tahun & 2 & 2 & 2 & 3 & 33.3 & 33.3 & 33.3 & 50 \\
\hline 4 tahun & 1 & 1 & 2 & 3 & 16.7 & 16.7 & 33.3 & 50 \\
\hline 5 tahun & 3 & 3 & 2 & 0 & 50 & 50 & 33.4 & 0 \\
\hline Total & 6 & 6 & 6 & 6 & 100 & 100 & 100 & 100 \\
\hline \multicolumn{9}{|l|}{ Jenis Kelamin } \\
\hline Laki-laki & 3 & 2 & 4 & 2 & 50 & 33.3 & 66.7 & 33.3 \\
\hline Perempuan & 3 & 4 & 2 & 4 & 50 & 66.7 & 33.3 & 66.7 \\
\hline Total & 6 & 6 & 6 & 6 & 100 & 100 & 100 & 100 \\
\hline \multicolumn{9}{|c|}{$\begin{array}{l}\text { Tingkat kecemasan sebelum } \\
\text { intervensi storytelling \& } \\
\text { guided imagery }\end{array}$} \\
\hline - Cemas sedang & 1 & 1 & 1 & 2 & 16.7 & 16.7 & 16.7 & 33.3 \\
\hline - Cemas sedang-berat & 2 & 2 & 3 & 2 & 33.3 & 33.3 & 50 & 33.3 \\
\hline - Cemas berat & 3 & 3 & 2 & 2 & 50 & 50 & 33.3 & 33.4 \\
\hline Total & 6 & 6 & 6 & 6 & 100 & 100 & 100 & 100 \\
\hline \multicolumn{9}{|c|}{$\begin{array}{l}\text { Tingkat kecemasan sesudah } \\
\text { intervensi storytelling \& } \\
\text { guided imagery }\end{array}$} \\
\hline - Cemas ringan & 0 & 1 & 2 & 1 & 0 & 16.7 & 33.3 & 16.7 \\
\hline $\begin{array}{l}\text { - Cemas ringan-sedang } \\
\text { - Cemas sedang }\end{array}$ & 1 & 2 & 1 & 2 & 16.7 & 33.3 & 16.7 & 33.3 \\
\hline \multirow[t]{2}{*}{ - Cemas sedang-berat } & 3 & 2 & 3 & 3 & 50 & 33.3 & 50 & 50 \\
\hline & 2 & 1 & 0 & 0 & 33.3 & 16.7 & 0 & 0 \\
\hline Total & 6 & 6 & 6 & 6 & 100 & 100 & 100 & 100 \\
\hline
\end{tabular}

Berdasarkan tabel 1 karakteristik responden berdasarkan usia didapatkan mayoritas responden berusia 3 tahun yaitu sebanyak 9 orang (37.5\%). Sedangkan jenis kelamin sebagian besar responden berjenis kelamin perempuan yaitu sebanyak 13 orang 
$(54,2 \%)$. Tingkat kecemasan anak sebelum intervensi storytelling dan guided imagery umumnya berada pada tingkat kecemasan berat yaitu sebanyak 10 orang $(41,7 \%)$, sedangkan tingkat kecemasan setelah intervensi yang terbanyak berada pada tingkat kecemasan sedang yaitu sebanyak 11 orang $(45,8 \%)$.

\section{Analisa Bivariat \\ Tingkat Kecemasan Anak Sebelum dan Sesudah Intervensi Storytelling dan Guided Imagery}

Tabel. 2

Perbedaan Rata-Rata Tingkat Kecemasan Anak Sebelum dan Sesudah Intervensi Storytelling dan Guided Imagery

\begin{tabular}{|c|c|c|c|c|c|c|}
\hline \multirow[t]{2}{*}{ Variabel } & \multirow[t]{2}{*}{ Mean } & \multirow[t]{2}{*}{ SD } & \multicolumn{2}{|c|}{$95 \% \mathrm{CI}$} & \multirow[t]{2}{*}{ P-value } & \multirow[t]{2}{*}{$\mathrm{n}$} \\
\hline & & & Lower & Upper & & \\
\hline \multicolumn{7}{|l|}{ Storytelling } \\
\hline \multicolumn{7}{|c|}{$\begin{array}{l}\text { Kelompok anak yang ditemani } \\
\text { orangtua }\end{array}$} \\
\hline - $\quad$ Sebelum & 4.33 & 0.816 & 1.135 & 3.198 & 0.003 & 6 \\
\hline - $\quad$ Sesudah & 2.17 & 0.753 & & & & \\
\hline$-\quad$ Selisih & 2.16 & & & & & \\
\hline \multicolumn{7}{|c|}{$\begin{array}{l}\text { Kelompok anak yang tidak } \\
\text { ditemani orangtua }\end{array}$} \\
\hline - Sebelum & 4.33 & 0.816 & 1.405 & 2.262 & 0.000 & 6 \\
\hline - $\quad$ Sesudah & 2.50 & 1.049 & & & & \\
\hline - $\quad$ Selisih & 1.83 & & & & & \\
\hline \multicolumn{7}{|c|}{ Guided Imagery } \\
\hline \multicolumn{7}{|c|}{$\begin{array}{l}\text { Kelompok anak yang ditemani } \\
\text { orangtua }\end{array}$} \\
\hline - $\quad$ Sebelum & 4.17 & 0.753 & 1.336 & 2.664 & 0.001 & 6 \\
\hline - $\quad$ Sesudah & 2.17 & 0.983 & & & & \\
\hline$-\quad$ Selisih & 2.00 & & & & & \\
\hline \multicolumn{7}{|c|}{$\begin{array}{l}\text { Kelompok anak yang tidak } \\
\text { ditemani orangtua }\end{array}$} \\
\hline - $\quad$ Sebelum & 4.00 & 0.894 & 1.125 & 2.209 & 0.001 & 6 \\
\hline - $\quad$ Sesudah & 2.33 & 0.816 & & & & \\
\hline - $\quad$ Selisih & 1.67 & & & & & \\
\hline
\end{tabular}

Berdasarkan tabel 2 menunjukkan intervensi storytelling dapat menurunkan tingkat kecemasan pada kelompok anak yang ditemani orangtua yaitu dengan $p$ value= 0.003 dan pada kelompok anak yang tidak ditemani orangtua $p$ value $=0.000$, artinya secara stastistik ada perbedaan yang signifikan tingkat kecemasan anak sebelum dan sesudah diberikan intervensi storytelling.

Tabel 2 juga menunjukkan bahwa intervensi guided imagery dapat menurunkan tingkat kecemasan pada kelompok anak yang ditemani orangtua pada saat pemasangan infus dengan nilai $p$ value $=0.001$ dan pada kelompok anak yang tidak ditemani orangtua $p$ value $=0.001$, artinya secara stastistik ada perbedaan yang signifikan tingkat kecemasan anak sebelum dan sesudah diberikan intervensi guided imagery. 


\section{PEMBAHASAN}

\section{Karakteristik Responden \\ Usia}

Usia anak dalam pemberian storytelling dan guided imagery adalah anak usia prasekolah yaitu anak yang berusia 3- 5 tahun. Usia terbanyak pada penelitian ini yaitu berusia 3 tahun (37,5\%). Pada tahap praoperasional menurut teori Piaget, anak belajar menggunakan dan mempresentasikan objek dengan gambaran dan kata-kata. Pemikirannya masih bersifat egosentris, anak kesulitan untuk melihat dari sudut pandang orang lain. Ciri dari tahapan ini adalah operasi mental yang jarang dan secara logika tidak memadai (Yuniarti, 2015).

Anak sering menggangap perawatan di rumah sakit sebagai hukuman. Ketakutan anak terhadap perlukaan muncul karena anak mengganggap prosedur yang dilakukan akan mengancam integritas tubuhnya. Oleh karena itu hal ini menimbulkan reaksi agresif, marah, cemas, takut dan tidak mau bekerjasama dengan perawat (Oktiawati, 2017).

Tidak kooperatifnya anak dengan perawat akan menghambat perawatan yang akan dilakukan sehingga lama rawat anak akan bertambah. Oleh karena itu dibutuhkan tindakan atraumatic care untuk mencegah terjadinya distress fisik maupun psikologis pada anak. Storytelling dan guided imagery dapat diterapkan kepada anak usia prasekolah sebagai salah satu cara atraumatic care untuk menurunkan tingkat kecemasan anak yang akan dilakukan tindakan pemasangan infus.

\section{Jenis Kelamin}

Proporsi terbesar pada karakteristik jenis kelamin adalah jenis kelamin perempuan $(54,2 \%)$. Hal ini berhubungan dengan jumlah responden yang masuk ke ruang rawat anak lebih banyak perempuan. Reaksi anak terhadap hospital dipengaruhi oleh faktor jenis kelamin (Wong, 2009). Meskipun jenis kelamin bukan faktor dominan terhadap munculnya kecemasan, tetapi ada penelitian yang mengatakan bahwa tingkat kecemasan yang tinggi terjadi pada wanita dibanding dengan laki-laki yaitu 2:1 (Suryanti, 2012).

\section{Pengaruh Storytelling terhadap Tingkat Kecemasan Anak Usia Prasekolah yang Dilakukan Tindakan Invasif Pemasangan Infus pada Anak}

Rata-rata tingkat kecemasan anak usia prasekolah yang dilakukan tindakan invasif pemasangan infus sebelum intervensi storytelling pada kelompok anak yang ditemani orang tua berada pada kecemasan sedang-berat dan sesudah intervensi terjadi penurunan kecemasan yaitu kecemasan ringan-sedang. Hasil uji paired t test didapatkan bahwa ada pengaruh yang signifikan tingkat kecemasan anak sebelum dan sesudah intevensi storytelling $(p$ value $=0.003$ ). Adanya penurunan tingkat kecemasan pada anak karena ada media sebagai pengalihan perhatian anak ketika akan dilakukan pemasangan infus. Menurut Potter \& Perry (2005) kecemasan yang terjadi disebabkan karena otak menstimulasi saraf otonom sehingga terjadi pelepasan epinefrin oleh kelenjar adrenal. Adanya stimulus yang menyenangkan maka endorphin akan dilepaskan sehingga dapat menghambat stimulus cemas sehingga cemas yang dikirimkan ke otak bisa.

Penelitian ini, kelompok responden yang ditemani orang tua pada saat pemasangan infus sebagian besar ditemani oleh orang tua khususnya ibu. Hal ini terkait dengan kedekatan ibu terhadap anak lebih dibanding ayahnya. Kedekatan ibu memberikan ketenangan bagi anak. Kenyamanan pada anak juga akan terpenuhi khususnya kenyamanan psikologis dan sosiokultural sehingga anak akan kooperatif, 
tidak menangis selama tindakan (Mariyam, 2011). Anak usia prasekolah membutuhkan bimbingan maupun dukungan dari orang tuanya karena pada usia ini hal yang paling ditakutkan adalah perpisahan dengan orang tua (Wong, 2009).

Rata-rata tingkat kecemasan anak usia prasekolah yang dilakukan tindakan invasif pemasangan infus sebelum intervensi storytelling pada kelompok anak yang tidak ditemani orang tua berada pada kecemasan sedang-berat dan sesudah intervensi terjadi penurunan kecemasan yaitu kecemasan ringan-sedang. Alasan anak tidak ditemani orangtua karena pada saat pemasangan infus orangtua tidak berada di tempat dan anak harus segera dilakukan pemasangan infus. Hasil uji paired t test didapatkan bahwa ada pengaruh yang signifikan tingkat kecemasan anak sebelum dan sesudah intervensi storytelling ( $p$ value $=0.000$ ).

Hasil penelitian diatas sejalan dengan penelitian yang dilakukan oleh Yati (2017) dimana terdapat pengaruh yang signifikan storytelling terhadap tingkat kecemasan anak usia prasekolah selama hospitalisasi. Dimana dengan storytelling dapat meningkatkan sikap anak dan dapat mengalihkan kecemasan. Anak yang mengalami kecemasan akan meningkatkan hormon epineprin dalam tubuh karena dapat meningkatkan oksigen dan glukosa ke otak dan otot dengan meningkatkan detak jantung. Namun, dengan storytelling dapat mengurangi peningkatan epineprin yang menyebabkan kecemasan. Story telling juga merupakan salah satu kegiatan yang bisa mengembangkan kecerdasan bahasa anak, dimana kegiatan ini mampu melatih kreatifitas anak dalam perkembangannya, kepekaan, kehalusan budi, emosi, seni, daya fantasi dan berimajinasi anak (Niswah, 2013). Hasil penelitian ini juga sejalan dengan penelitian yang dilakukan Padila (2019) yang menunjukkan bahwa perlakuan dengan menggunakan story telling (bercerita) lebih signifikan menurunkan ansietas pada anak usia pra sekolah.

Pada penelitian ini didapatkan selisih antara kelompok anak yang ditemani orangtua yaitu sebesar 2.16, sedangkan pada kelompok anak yang tidak ditemani orangtua besar selisih 1.83. Hal ini menunjukkan bahwa intervensi storytelling lebih berpengaruh pada kelompok anak yang ditemani orangtua dibandingkan dengan anak yang tidak ditemani orangtua. Keterlibatan orangtua saat anak dilakukan tindakan invasif pemasangan infus akan memberikan perasaan tenang, nyaman dan dapat memfasilitasi penguasaan anak terhadap lingkungan sekitar. Kehadiran orangtua sangat penting bagi anak yang sedang mengalami suatu tindakan yang akan menimbulkan kecemasan, karena kehadiran orang yang dicintai juga akan meminimalkan kesepian dan ketakutan klien (Potter \& Perry, 2005).

Selain kehadiran orangtua dapat mempengaruhi penurunan tingkat kecemasan anak, ditemukan adanya faktor lain yaitu jenis cerita. Jenis cerita yang deberikan yaitu cerita fabel (binatang yang bisa berbicara) dan dongeng. Dalam peneltian ini cerita terbanyak yang dipilih anak yaitu cerita tentang binatang yang sedang mengalami masalah tapi kemudian bisa terselesaikan. Setiap cerita mengandung nilai moral sehingga dapat menumbuhkan rasa percaya diri anak, rasa aman, tentram, menanamkan rasa peka dalam batinnya untuk bisa membedakan mana yang baik dan yang buruk, menanamkan tentang kebenaran dan keadilan, keberanian dan kejujuran. Beberapa kekuatan cerita yaitu untuk menumbuhkan sikap disiplin, memunculkan perubahan, menumbuhkan kekuatan pikiran dan emosional (Susanti, 2017).

Cerita lain yang dapat diberikan yaitu dongeng dan cerita rakyat menarik yang disukai anak. Cerita yang menarik akan membuat anak mau fokus dan tetap mendengar cerita yang diberikan. Anak dengan kecemasan sedang memungkinkan anak berfokus pada hal yang penting dan mengesampingkan hal yang lain (Apriliawati, 2011). 
Menurut Kanchan (2015) storytelling direkomendasikan sebagai tindakan nonfarmakologis untuk merawat dan menyembuhkan anak karena mudah, tidak mahal, dapat diakses dan metode yang disukai anak.

\section{Pengaruh Guided Imagery terhadap Tingkat Kecemasan Anak yang Dilakukan Tindakan Invasif Pemasangan Infus pada Anak yang Ditemani Orang Tua dan yang Tidak Ditemani Orang Tua}

Rata-rata tingkat kecemasan anak usia prasekolah yang dilakukan tindakan invasif pemasangan infus sebelum intervensi guided imagery pada kelompok anak yang ditemani orang tua berada pada tingkat kecemasan sedang-berat dan sesudah intervensi guided imagery kecemasan anak menurun ke tingkat kecemasan ringan-sedang. Hasil uji paired t test didapatkan bahwa ada pengaruh yang signifikan tingkat kecemasan anak sebelum dan sesudah intervensi guided imagery $(p$ value $=0.001)$.

Adanya perbedaan tingkat kecemasan yang terjadi berhubungan dengan mekanisme guided imagery yang merupakan teknik relaksasi sehingga dapat melemahkan psikoneuroimunologi yang mempengaruhi respon stres. Ini berkaitan dengan teori gate control yang menyatakan bahwa "hanya satu impuls yang dapat berjalan sampai sumsum tulang ke otak dalam satu waktu" dan jika impuls ini diisi dengan pikiran lain maka sensasi rasa sakit maupun kecemasan tidak dapat dikirim ke otak oleh karena itu rasa sakit ataupun cemas akan berkurang" (Mariyam, 2011). Menggunakan guided imagery akan mengurangi kecemasan anak, karena guided imagery merupakan sebuah pengalihan.

Perbedaan yang signifikan juga dikarenakan guided imagery dapat mempengaruhi semua kontrol fisiologis dalam tubuh termasuk pernapasan, denyut jantung dan tekanan darah. Guided imagery telah terbukti dapat menurunkan kecemasan dan nyeri pada pasien yang dilakukan pembedahan, hal ini dibuktikan oleh kurangnya penggunaan obat-obatan. Guided imagery dapat mempengaruhi keseimbangan tubuh dengan cara fokus pada pikiran, menurunkan simpatis dan meningkatkan sistem neurokimia saraf parasimpatis (Forward, 2015).

Rata-rata tingkat kecemasan anak usia prasekolah yang dilakukan tindakan invasif pemasangan infus sebelum dan sesudah intervensi guided imagery pada kelompok anak yang tidak ditemani orang tua, peningkatan dengan nilai selisih $=1.67$. Hasil uji paired $t$ test didapatkan bahwa ada pengaruh yang signifikan tingkat kecemasan anak sebelum dan sesudah intervensi guided imagery $(p$ value $=0.001)$.

Hart (2008) juga menyatakan bahwa imajinasi positif atau yang menyenangkan dapat mengurangi gejala sakit maupun cemas. Menurut Kolcaba Alves \& Khatarine (2009) pemberian guided imagery pada anak yang dilakukan pemasangan infus merupakan intervensi keperawatan untuk memenuhi kebutuhan rasa nyaman fisik pada anak, bentuk kenyamanan yang diberikan yaitu kenyamanan reliefe (status ketidaknyamanan anak berkurang). Alves \& Khatarine (2009) guided imagery membantu untuk merelaksasi dan memberikan efek positif terhadap tubuh, melepas ketidaknyamanan yang dialami oleh individu.

Pikiran yang positif dapat mengurangi keadaan yang tertekan yang berhubungan dengan ketidaknyamanan. Guided imagery dapat membantu melawan pikiran yang negatif dan dapat memperkuat diri seseorang dan pribadi yang berkualitas. Kehidupan yang berkualitas berkontribusi dalam pengalaman positif yang meningkatkan nilai positif, sehingga melalui persepsi, emosi dan psikologi dapat menigkatkan sikap positif seseorang (Alves \& Khatarine, 2009). 
Hasil analisis pengaruh guided imagery terhadap kecemasan anak usia prasekolah yang dilakukan pemasangan infus pada kelompok anak yang ditemani orang tua dan yang tidak ditemani orang tua ditemukan adanya perbedaan nilai selisih dimana nilai selisih tertinggi yaitu tingkat kecemasan anak yang ditemani oleh orang tua. Perbedaan nilai selisih ini disebabkan karena faktor kehadiran orang tua dan juga lingkungan. Kehadiran orang tua dapat memberikan kenyamanan psikologis dan sosiokultural pada anak (Mariyam, 2011). Selain itu lingkungan yang dimodifikasi seperti menata ruangan bernuansa anak juga dapat mencegah atau menghindari distress fisik anak (Oktiawati, 2017)

\section{Integrasi Teori Keperawatan Caring pada Storytelling dan Guided Imagery terhadap Tingkat Kecemasan Anak Usia Prasekolah yang Dilakukan Tindakan Invasif (Pemasangan Infus)}

Beberapa penelitian telah dilakukan untuk menurunkan tingkat kecemasan anak yang menjalani hospitalisasi dan yang akan dilakukan tindakan invasif. Storytelling dan guided imagery merupakan salah satu tindakan atraumatic care yang berbasis caring.

Maintaining belief yaitu memelihara kepercayaan anak dan juga keluarga. Perawat menanggapi semua keluhan yang diberikan anak, perawat membantu dengan tulus, dan perawat tetap bersikap optimis terhadap kesembuhan klien. Melalui kegiatan ini bisa terjadi hubungan saling percaya antara perawat dan anak, anak mempertahankan sikap positif dengan bersikap kooperatif sehingga tidak menghambat proses perawatan selama dirawat di rumah sakit.

Knowing yaitu memahami makna pengalaman hidup klien dengan menggali informasi klien secara detail, mencari dan mengkaji hal-hal yang terkait yang berhubungan dengan orang terdekat. Pada tahap ini peneliti menanyakan cerita kesukaan anak, kebiasaan yang dilakukan anak, hubungan dengan orantua atau dengan orang terdekat, mencari tahu tentang pengalaman infus sebelumnya dan hal yang membuat anak merasa cemas.

Being with yaitu bersama klien, berbagi perasaan secara emosional dengan perasaan tanpa beban. Peneliti bersama dengan keluarga bekerjasama untuk bisa menerapkan intervensi storytelling maupun guided imagery agar kecemasan anak tentang pemasangan infus akan menurun.

Doing for yaitu perawat bersama dengan klien berbuat sesuatu secara terampil, menyediakan kebutuhan yang dibutuhkan, memberikan kenyamanan, menjaga privasi klien. Pada tahap ini, perawat memberikan intervensi yang atraumatik yaitu distress psikologis yang berbasis caring yaitu terapi storytelling dan guided imagery untuk menurunkan kecemasan anak pada saat pemasangan infus.

Enablings yaitu mendukung, memampukan anak dan keluarga dengan cara menjelaskan kepada anak dan keluarga tentang storytelling dan guided imagery sehingga anak bisa memahami kemampuannya, memberdayakan orangtua/ keluarga untuk selalu terlibat dalam setiap prosedur yang dilakukan sebagai intervensi keperawatan yang berpusat pada keluarga (Family Center Care).

Caring merupakan salah satu tindakan atraumatic care yang sangat diperlukan untuk memberikan asuhan keperawatan kepada anak terutama anak yang sedang cemas karena hospitalisasi ataupun terhadap suatu prosedur invasif tertentu (Alligood, 2014). 


\section{SIMPULAN}

Sebagian besar responden berusia 3 tahun, berjenis kelamin perempuan. Tingkat kecemasan anak usia prasekolah pada kelompok anak yang ditemani orangtua yang dilakukan tindakan invasif (pemasangan infus) sebelum diberikan intervensi storytelling yaitu tingkat kecemasan sedang-berat dan sesudah dilakukan intervensi tingkat kecemasan anak ringan-sedang. Tingkat kecemasan anak usia prasekolah pada kelompok anak yang tidak ditemani orangtua yang dilakukan tindakan invasif (pemasangan infus) sebelum diberikan intervensi storytelling yaitu yaitu tingkat kecemasan sedang-berat dan sesudah dilakukan intervensi tingkat kecemasan anak ringan-sedang.

Tingkat kecemasan anak usia prasekolah pada kelompok anak yang ditemani orangtua yang dilakukan tindakan invasif (pemasangan infus) sebelum diberikan intervensi guided imagery yaitu tingkat kecemasan sedang-berat dan sesudah dilakukan intervensi tingkat kecemasan anak ringan-sedang. Tingkat kecemasan anak usia prasekolah pada kelompok anak yang tidak ditemani orangtua yang dilakukan tindakan invasif (pemasangan infus) sebelum diberikan intervensi storytelling yaitu tingkat kecemasan sedang-berat dan sesudah dilakukan intervensi tingkat kecemasan anak ringan-sedang

Ada pengaruh pemberian storytelling dan guided imagery terhadap tingkat kecemasan anak yang dilakukan tindakan invasif (pemasangan infus) pada kelompok anak yang ditemani orangtua maupun yang tidak. Selisih penurunan tingkat kecemasan tertinggi yaitu dengan menggunakan intervensi storytelling atau dapat disimpulkan bahwa storytelling kepada kelompok anak usia prasekolah yang ditemani orangtua lebih berpengaruh dibandingkan kepada anak yang tidak ditemani orangtua.

\section{SARAN}

\section{Bagi Pelayanan Kesehatan}

Disarankan kepada petugas kesehatan dapat menerapkan teknik storytelling maupun guided imagery pada anak usia prasekolah yang mengalami hospitalisasi khususnya ketika dilakukan tindakan invasif (pemasangan infus) untuk menurunkan tingkat kecemasan anak dan memotivasi orangtua untuk selalu hadir menemani anak.

\section{Bagi Pasien dan Keluarga}

Storytelling dan guided imagery dapat dilakukan oleh keluarga sebagai perawatan yang berpusat pada keluarga (Family Center Care) dimana storytelling dan guided imagery merupakan salah satu cara untuk mengalihkan perhatian anak dan memberikan rasa nyaman pada anak yang dilakukan tindakan invasif (pemasangan infus).

\section{Bagi Peneliti Keperawatan}

Peneliti menyarankan untuk melakukan penelitian lebih lanjut tentang pengaruh storytelling terhadap tingkat kecemasan anak yang dilakukan pemasangan infus dengan mempersiapkan jenis cerita yang lebih bervariasi. Perlu adanya penelitian lebih lanjut tentang pengaruh guided imagery terhadap kecemasan anak yang dilakukan tindakan invasif (pemasangan infus) pada anak dengan usia yang berbeda, sampel yang lebih banyak dan tempat yang berbeda. Disarankan untuk mencoba mengkombinasi intervensi storytelling dan guided imagery dengan intervensi yang lain. 


\section{DAFTAR PUSTAKA}

Alligood, M. R. (2014). Nursing Theory and Their Work $8^{\text {th }}$ Edition. St. Louis: Elsevier Inc

Alves, J. L., \& Katharine, K. (2009). The Effects of Guided Imagery on Comfort, Depression, Anxiety, and Stress of Psychiatric Inpatients with Depressive Disorders. Published by Elsevier Inc

Apriliawati, A., Nurhaeni N., \& Besral, B. (2011). Pengaruh Biblioterapi terhadap Tingkat Kecemasan Anak Usia Sekolah yang Menjalani Hospitalisasi di Rumah Sakit Islam Jakarta. Fakultas Magister Keperawatan. Universitas Indonesia

Forward, J. B., Nancy, E. G., Santa, J. C., \& Houston, F. L. (2015). Effect of Structured Touch and Guided Imagery for Pain and Anxiety in Elective Joint Replacement Patients- A Randomized Controlled Trial: M-TIJRP, The Permanente Journal/ Fall, 19(4), 18-28

Hart, J. (2008). Guided Imagery. Mary Ann Liebert, INC, 14(6), 295-299

Irmawaty, L. (2013). Pengaruh Storytelling terhadap Tingkat Kecemasan Akibat Hospitalisasi pada Anak Usia Prasekolah di RSUD Kota Bekasi

Kanchan, L., Sharma, M. C., \& Sareen, A. (2015). A Randomized Clinical Trial to Evaluate the Effectiveness of Storytelling by Researcher on the Hospitalization Anxiety of Children Admitted in Pediatric Ward of Selected Hospitals of District Patiala, Punjab. International Journal of Science and Research (IJSR), 4(10), 2319-7064

Mariyam., Nurhaeni, N., 7 Besral, B. (2011). Pengaruh Guided Imagery terhadap Tingkat Nyeri Anak Usia 7-13 Tahun Saat Dilakukan Pemasangan Infus di RSUD Kota Semarang. Universitas Indonesia

Niswah, S., \& Prasetyarini, A. (2013). Pengaruh Metode Storytelling terhadap Pengembangan Minat Baca dan Bahasa Anak Kelompok B di TK Tunas Bangsa Pati Tahun Ajaran 2012/ 2013. Universitas Muhammadiyah Surakarta

Oktiawati, A., Khodijah, K., Ikawati, S., \& Rizky, C. D. (2017). Teori dan Konsep Keperawatan Pediatrik. Jakarta: Trans Info Media

Padila, P., Agusramon, A., \& Yera, Y. (2019). Terapi Story Telling dan Menonton Animasi Kartun terhadap Ansietas. Journal of Telenursing (Joting), 1(1), 51-66

Patasik, C. H., Tangka, J., \& Rottie, J. (2013). Efektifitas Teknik Relaksasi Nafas Dalam dan Guided Imagery terhadap Penurunan Nyeri pada Pasien Post Operasi Sectio Caesarea di Irina D Blu Rsup Prof. Dr. R. D. Kandou Manado. Universitas Sam Ratulangi Manado

Potter, P. A., \& Perry, A. G (2005). Buku Ajaran Fundemental Keperawatan : Konsep, Proses dan Praktek Edisi 8. Volume 2. Jakarta: EGC

Siregar, J. R., Anggia, P. A., Langgersari E. N., \& Edi, S. T. (2015). Penerapan Storytelling sebagai Intervensi untuk Menurunkan Derajat Stres pada Anak Leukemia. Indonesian Journal of Cancer, 9(4), 147-158

Suryanti, S., Sodikin, S., \& Yulistiani, M. (2012). Pengaruh Terapi Bermain Mewarnai dan Origami terhadap Tingkat Kecemasan sebagai Efek Hospitalisasi pada Anak Usia Pra Sekolah di RSUD dr. R. Goetheng Taruna di Brata Purbalingga. Jurnal Ilmiah Ilmu-Ilmu Kesehatan, 10(1), 38-44

Susanti, A., \& Handika, S. (2017). Pengaruh Storytelling terhadap Tingkat Kecemasan Anak Prasekolah yang Menjalani Hospitalisasi di RS DR. Djamil Padang. Jurnal Ilmu Kesehatan, 1(1), 2597-8594 
Wong, D. L., Hockenberry, H., Wilson, D., Winkelsein, M. L., \& Schwatrz, P. (2009). Buku Ajar Keperawatan Pediatrik. (edisi 6) (Monika Ester penterjemah). Jakarta: EGC

Yati, M., Sri, W., Dewi, S. P., \& Islali, I. (2017). The Effect of Storytelling in a Play Therapy on Anxiety Level in Pre-School Children during Hospitalization in the General Hospital of Buton. Public Health of Indonesia, 3(3), 2477-1570

Yuniarti, S. (2015). Asuhan Tumbuh Kembang Neonatus, Bayi-Balita dan Anak Prasekolah. Bandung: PT Refika Aditama 